Annals of Warsaw University of Life Sciences - SGGW

Land Reclamation No 45 (2), 2013: 125-141

(Ann. Warsaw Univ. of Life Sci. - SGGW, Land Reclam. 45 (2), 2013)

\title{
Modelling of discharge, nitrate and phosphate loads from the Reda catchment to the Puck Lagoon using SWAT
}

\author{
PAWEŁ MARCINKOWSKI, MIKOŁAJ PINIEWSKI, IGNACY KARDEL, \\ MAREK GIEŁCZEWSKI, TOMASZ OKRUSZKO \\ Department of Hydraulic Engineering, Warsaw University of Life Sciences - SGGW
}

\begin{abstract}
Modelling of discharge, nitrate and phosphate loads from the Reda catchment to the Puck Lagoon using SWAT. This study presents an application of the SWAT model (Soil and Water Assessment Tool) in an agricultural, coastal catchment situated in northern Poland, draining an area of $482 \mathrm{~km}^{2}$ (the Reda catchment). The main objective of this study was calibration and validation of the model against daily discharge and water quality parameters (bi-monthly total suspended solids [TSS], nitrate nitrogen $\left[\mathrm{N}-\mathrm{NO}_{3}\right]$ and phosphate phosphorus $\left[\mathrm{P}-\mathrm{PO}_{4}\right]$ loads). Calibration and validation were conducted using the SWAT-CUP program and SUFI-2 (Sequential Uncertainty Fitting Version 2) algorithm. The Nash-Sutcliffe efficiency, which was set as an objective function in calibration of all variables, was equal for discharge to 0.75 and 0.61 for calibration and validation periods, respectively. For TSS, $\mathrm{N}-\mathrm{NO}_{3}$ and $\mathrm{P}_{-} \mathrm{PO}_{4}$ loads NSE was equal to 0.56, 0.62 and 0.53 in calibration period, and $0.22,0.64$ and -1.78 in validation period, respectively. For the calibration period all the results are satisfactory or good, while for the validation period the results for TSS and $\mathrm{P}_{-} \mathrm{PO}_{4}$ loads are rather poor, which is related mainly to the lack of homogeneity between calibration and validation periods. These results demonstrate that SWAT is an appropriate tool for quantification of nutrient loads in Polish agricultural catchments, in particular for $\mathrm{N}-\mathrm{NO}_{3}$. The model can therefore be applied for water resources management, for quantification of scenarios of climate and land use change, and for estimation of the Best Management Practices efficiency.
\end{abstract}

Key words: Reda catchment, Puck Lagoon, SWAT model, nutrients, discharge, calibration

\section{INTRODUCTION}

Sustainable management of water quantity and quality has recently become a major issue in the face of decreasing water resources and increasing water demand throughout the country (Kundzewicz et al. 2010). According to the surface water availability index (annual out-flow magnitude divided by the number of inhabitants), Poland - with very low water resources - is classified at the bottom of the list of the European countries (Mioduszewski 2008). In addition, the rapid economic development and agriculture intensification in Poland during the $20^{\text {th }}$ century led to the increasing scale of eutrophication of the Baltic Sea (Glasby and Szefer 1998), due to excessive loadings of biogenic substances such as nitrates and phosphates. In order to prevent this negative phenomenon and reverse the trend, complex activities, resulting from the regulations of the Water Framework Directive (2000) have to be undertaken. One of the tasks related to the provision of the WFD is development of effective monitoring system necessary to track and investigate the environmental response to alterations in catchment management. However, the assembled dataset of observations does not explain 
the processes by itself, but only presents the final response, leaving the driving forces, which trigger the changes, uninvestigated. Hence, a modelling tool such as the Soil and Water Assessment Tool - SWAT (Neitsch et al. 2011) can be helpful in providing a detailed description of processes occurring in catchment through simulations transforming input data into output signal determining the water quantity and quality. The SWAT model has proven to be an effective simulation tool, which is manifested by its growing worldwide use (Arnold et al. 2012), in particular in the USA (Srinivasan et al. 1998, Amatya et al. 2008), in the Baltic Sea region: in Finland (Tattari et al. 2009), Sweden (Ekstrand et al. 2010), Denmark (Hoang et al. 2012), and Poland (Ostojski 2012, Piniewski et al. 2013, Smarzyńska 2013). This study was carried out in the Reda catchment situated in northern Poland (Fig. 1), draining an area of $482 \mathrm{~km}^{2}$ to the Puck Lagoon (inner Puck Bay, part of the Gulf of Gdańsk). Its objective was to: (1) develop the model set-up of the Reda catchment, (2) calibrate and validate the model against daily water discharge, and bi-monthly measurements of total suspended sediment (TSS), nitrate nitrogen $\left(\mathrm{N}-\mathrm{NO}_{3}\right)$ and phosphate phosphorus $\left(\mathrm{P}-\mathrm{PO}_{4}\right)$ loads.

\section{MATERIAL AND METHODS}

\section{Study area}

The River Reda is situated in northern Poland in Pomeranian Province (Fig. 1), in the proximity of the Tricity (Gdańsk, Gdynia, Sopot) metropolitan area. Its drainage area equal to $482 \mathrm{~km}^{2}$ is the largest sub-catchment of the Puck Bay catchment. It belongs to the marine area of the Nadmorski Landscape Park, a designated HELCOM Baltic Sea Protected Area.

The annual mean basin-averaged precipitation is $793 \mathrm{~mm}$, while the average (1991-2010) daily minimum and maxi-

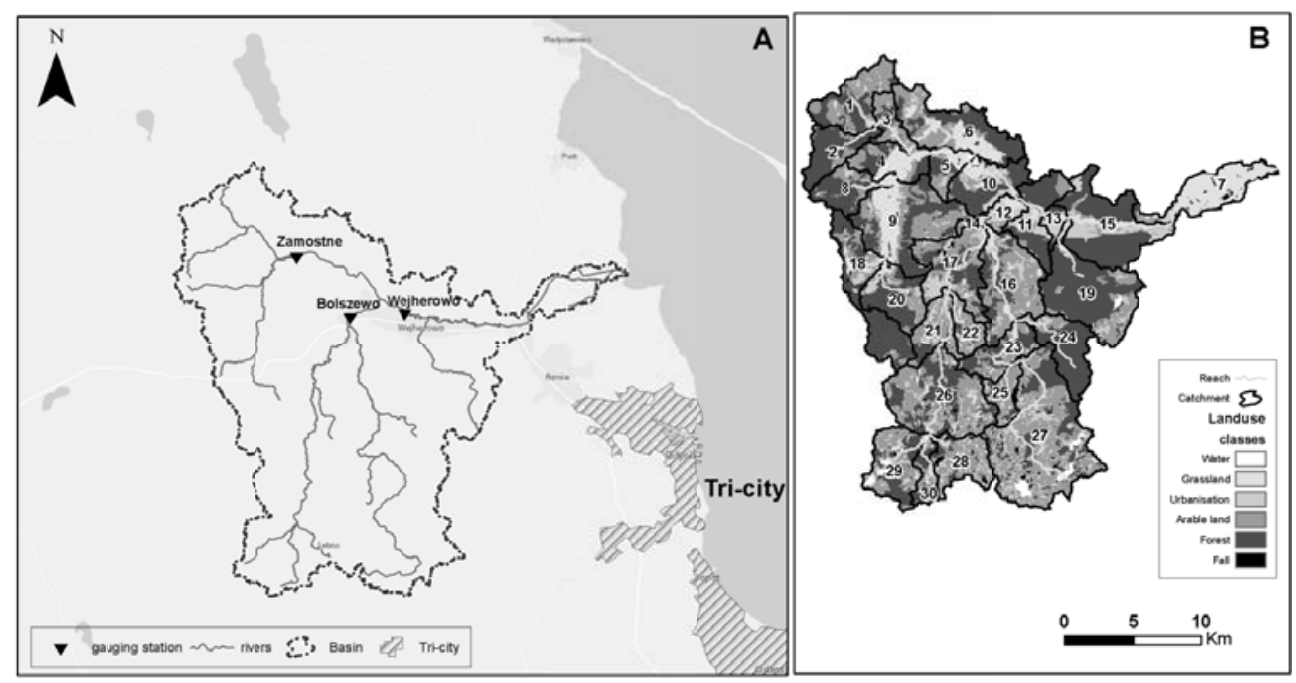

FIGURE 1. The Reda catchment (A) and its land cover map (B) 
mum temperatures are -1.5 and $2.9^{\circ} \mathrm{C}$ for January, and 15.4 and $21.5^{\circ} \mathrm{C}$ for July (based on the nearby Institute of Meteorology and Water Management - IMGW station in Gdynia).

The watershed is characterized by a hilly landscape, where the maximum elevation reaches $234 \mathrm{~m}$ a.s.l. and sandy soils dominate the landscape. In the northern part valley is filled with peat deposits that stretch from west to east. The catchment area is predominantly occupied by agricultural land (51.2\%) and forests $(41.6 \%)$, whereas the share of urban land yields $6.6 \%$. The prevailing crops on better quality soils are spring cereals, whereas potatoes and winter cereals on poor quality soils. The majority of grasslands are cultivated as permanent meadows and pastures.

$\mathrm{N}-\mathrm{NO}_{3}$ and $\mathrm{P}-\mathrm{PO}_{4}$ are the two most dominant forms of $\mathrm{N}$ and $\mathrm{P}$ species in the Reda waters (Bogdanowicz et al. 2007). For this reason, these two forms were selected for modelling in this study.

\section{Modelling tool}

SWAT is a physically based, semi-distributed, continuous-time model that operates on a daily time step and simulates the movement of water, sediment, and nutrients on a watershed scale. The smallest unit of discretization is a unique combination of land use, soil, and slope overlay, referred to as a hydrological response unit (HRU). Runoff is predicted separately for each HRU and then aggregated to the sub-basin level and routed through the stream network to the main outlet in order to obtain the total runoff for the river basin.

No matter what type of problem one studies with SWAT, water balance is the driving force behind everything that happens in the watershed. For this study, we selected the modified USDA Soil Conservation Service (SCS) curve number method for calculating surface runoff and the Penman-Monteith method for estimating potential evapotranspiration. Channel routing was modelled using a variable storage coefficient approach. SWAT uses the degree-day method for snowmelt estimation.

SWAT uses a plant growth model to simulate all types of land covers that is based on EPIC (Williams 1990). The plant growth model is used to assess removal of water and nutrients from the root zone, transpiration, and biomass/ /yield production. Erosion and sediment yield are calculated for each HRU using the Modified Universal Soil Loss Equation - MUSLE (Williams and Berndt 1977), which uses the amount of runoff as an indicator of erosive energy. Sediment transport in the channel network is a function of two processes, deposition and degradation. The occurrence of these processes is determined by the stream power, the exposure of a channel's sides and bottom to the erosive force of the stream and the composition of channel bank and bed sediment.

SWAT tracks the movement and transformation of several forms of nitrogen and phosphorus in the watershed. In the soil, the model simulates principal processes included in the nutrients cycle that control the transformation of nutrients from one form to another. In the nitrogen cycle, the main processes are: denitrification, nitrification, mineralization, plant uptake, decay, fertilization, volatilization, and in the phosphorus cycle they are: mineralization, fertilization, 
decay, and plant uptake. Nutrients may be introduced to the main channel and transported downstream through surface runoff and lateral subsurface flow. The in-stream water quality component allows the researcher to control nutrient transformations in the stream. The instream kinetics used in SWAT for nutrient routing are adapted from QUAL2E (Brown and Barnwell 1987). The model tracks two pools of nutrients: those dissolved in the stream and those adsorbed to the sediment. Dissolved nutrients are transported with the water while those adsorbed to sediments are allowed to be deposited with the sediment on the bed of the channel.

\section{Model setup}

In this study a 50-meter resolution Digital Elevation Model (DEM), acquired from Voivodeship Centre of Geodesy and Cartography Documentation in Gdańsk (WODGiK), has been used for automatic catchment delineation and its division into 30 sub-catchments (Fig. 1). From the Corine Land Cover Map (2006) 13 classes of land use were featured, whereas the numerical soil map from Institute of Soil Science and Plant Cultivation (IUNG) and geological map from Polish Geological Institute - National Research Institute (PIG-PIB) allowed to feature 17 classes of soils. Intersection of land use map, soil map, and slope classes resulted in creation of 465 Hydrologic Response Units (HRUs). Precipitation data from five stations, and other climate variables (temperature, wind speed, relative humidity and solar radiation) from four stations for time period 1991-2010 have been acquired from Institute of Meteorology and Water Management - National Research
Institute in Gdynia (IMGW-PIB). In the studied area four main point sources of pollutants were identified based on the data from Regional Water Management Authority in Gdańsk (RZGW). The calendars of management practices included nine main crops and were describing the exact dates, types of operations and their detailed parameterisation separately for each crop. The necessary information for defining these data was acquired from statistical data and interviews with the staff of the Pomeranian Agricultural Advisory Board in Gdańsk (PODR).

\section{Model calibration approach}

SWAT is a river-basin scale model, in which hydrological cycle drives the water, sediment and nutrient movement. Due to a large number of parameters, SWAT requires conducting calibration which includes fitting simulations to observations, usually by using automatic routines of various types. Calibration should be preceded by the sensitivity analysis which measures the response of model outputs and objective function to altering input parameter values. Model validation is usually conducted using calibrated parameter values for a different time period than the one used in calibration.

In this study in the Reda catchment, analyses were focused on four different variables (listed below) for which observations are regularly assembled and used in calibration and validation time periods as presented in brackets below. The entire process consisting of sensitivity analysis, calibration and validation was conducted in four iterations related to different variables simulated by the model: 
1. Discharge
a) Sensitivity analysis of parameters potentially affecting discharge,
b) Selection of calibration para- meters,
c) Calibration (time period 1998 -2002 ),
d) Validation (time period 2003- $-2006)$
e) Writing best fit parameter values into the SWAT project.

2. Total suspended sediment (TSS)

a) Sensitivity analysis of parameters potentially affecting TSS load (excluding the parameters selected in point $1 b$ ),

b) Selection of calibration parameters,

c) Calibration (time period 1998-2002 ),

d) Validation (time period 2003-2006),

e) Writing best fit parameter values into the SWAT project.

3. Nitrate nitrogen $\left(\mathrm{N}-\mathrm{NO}_{3}\right)$

a) Sensitivity analysis of parameters potentially affecting $\mathrm{N}-\mathrm{NO}_{3}$ load (excluding the parameters selected in point $1 b$ and $2 b$ ),

b) Selection of calibration parameters,

c) Calibration (time period 1998-2002 ),

d) Validation (time period 2003-2006),

e) Writing best fit parameters into the SWAT project.

4. Mineral phosphorus $\left(\mathrm{P}-\mathrm{PO}_{4}\right)$

a) Sensitivity analysis of parameters potentially affecting $\mathrm{P}_{-} \mathrm{PO}_{4}$ load (excluding the parameters selected in point $1 b, 2 b$ and $3 b$ ), b) Selection of calibration parameters,

c) Calibration (time period 1998-2002),

d) Validation (time period 2003-2006),

e) Writing best fit parameters into the SWAT project.

Simulation of nutrient loads is significantly conditioned by the hydrological cycle and thus the accuracy of calculations depends on the properly conducted calibration of discharge. The aim of this stage of calibration is to reflect spatial and temporal variability of water balance in the analysed catchment and to satisfactorily reproduce variability of daily streamflow.

Daily discharge time series from three gauging stations (the River Bolszewka at Bolszewo and the River Reda at Zamostne and Wejherowo, Fig. 1) were acquired from IMGW-PIB in order to perform step 1 from the aforementioned list. The following three steps concerned calibration of sediment, nitrate and mineral phosphorus loads, based on the dataset acquired from the General Inspectorate of Environmental Protection in Gdańsk (GIOŚ), containing bi-monthly measurements of sediment and nutrient concentrations of the Reda at Wejherowo between 1998 and 2006. Average daily loadings ( $\mathrm{kg}$ /day) of selected water quality parameters were calculated based on daily discharge data $\left(\mathrm{m}^{3} /\right.$ day $)$ at Wejherowo gauging station.

The SWAT-CUP program (Abbaspour 2008) was used for sensitivity analysis, calibration and validation. The main function of this tool is to provide a link between the input/output of a calibration program and the SWAT model through 
iterative altering of parameters values (selected beforehand during sensitivity analysis) using SUFI-2 (Sequential Uncertainty Fitting Version 2) algorithm that combines optimization with uncertainty analysis. Tables 1 and 2 show the parameter names and definitions used for calibration of discharge and TSS loads, and $\mathrm{N}-\mathrm{NO}_{3}$ and $\mathrm{P}_{-} \mathrm{PO}_{4}$ loads. The calibration process is considered as successfully completed when the satisfactory values of defined objective function (e.g. Nash-Sutcliffe efficiency - NSE; Moriasi et al. 2007), $p$-factor and $r$-factor (uncertainty parameters) are obtained.
The $p$-factor represents the percentage of measured data bracketed by a $95 \%$ prediction uncertainty (95PPU), and the $r$-factor quantifies the average thickness of the 95PPU uncertainty band divided by the standard deviation of the measured data. In this study NSE was used as an objective function for each of the model outputs, however, we kept track of other goodness-fit values (coefficient of determination $-\mathrm{R}^{2}$, percent bias - PBIAS) and uncertainty indicators ( $p$-factor, $r$-factor).

Each calibration/validation model run was performed with a warm-up period of

TABLE 1. Fitted parameter values and optimal parameter ranges calculated using SUFI-2 during calibration of discharge

\begin{tabular}{|c|c|c|c|c|}
\hline Parameter name $^{1}$ & Definition & $\begin{array}{l}\text { Fitted } \\
\text { value }\end{array}$ & $\begin{array}{l}\text { Mini- } \\
\text { mum } \\
\text { value }\end{array}$ & $\begin{array}{l}\text { Maxi- } \\
\text { mum } \\
\text { value }\end{array}$ \\
\hline r_CN2.mgt & $\begin{array}{l}\text { Initial SCS runoff curve number for moisture } \\
\text { condition II (-) }\end{array}$ & -0.038 & -0.10 & 0.01 \\
\hline v_GW_DELAY.gw & Groundwater delay time (day) & 397 & 250 & 500 \\
\hline r_GWQMN.gw & $\begin{array}{l}\text { Threshold depth of water in the shallow aquifer } \\
\text { required for return flow to occur }\left(\mathrm{mm} \mathrm{H}_{2} \mathrm{O}\right)\end{array}$ & -0.14 & -0.8 & 0.5 \\
\hline r_REVAPMN.gw & $\begin{array}{l}\text { Threshold depth of water in the shallow aquifer } \\
\text { for revap or percolation to the deep aquifer to } \\
\text { occur }\left(\mathrm{mm} \mathrm{H}_{2} \mathrm{O}\right)\end{array}$ & -0.32 & -0.5 & 1 \\
\hline r_SOL_Z.sol & $\begin{array}{l}\text { Depth from soil surface to bottom of layer } \\
\text { (mm) }\end{array}$ & 0.06 & -0.35 & 0.2 \\
\hline r__SOL_BD().sol & Moist bulk density $\left(\mathrm{g} / \mathrm{cm}^{3}\right)$ & 0.36 & -0.1 & 0.4 \\
\hline r_GW_REVAP.gw & Groundwater "revap" coefficient (-) & 0.46 & -0.6 & 0.6 \\
\hline v_ESCO.hru & Soil evaporation compensation factor (-) & 0.85 & 0.82 & 1 \\
\hline $\mathrm{v}$ & Snow pack temperature lag factor (-) & 0.36 & 0.2 & 0.8 \\
\hline $\mathrm{r} \_\mathrm{SOL} \_\mathrm{K}() \cdot \mathrm{sol}$ & Saturated hydraulic conductivity $(\mathrm{mm} / \mathrm{h})$ & -0.38 & -0.8 & 0 \\
\hline r_HRU_SLP.hru & Average slope steepness $(\mathrm{m} / \mathrm{m})$ & -0.02 & -0.45 & 0.1 \\
\hline v_EPCO.hru & Plant uptake compensation factor (-) & 0.02 & 0 & 0.5 \\
\hline v__SURLAG.bsn & Surface runoff lag coefficient (-) & 0.1 & 0.05 & 0.45 \\
\hline r_RCHRG_DP.gw & Deep aquifer percolation fraction (-) & -0.05 & -0.8 & 0.8 \\
\hline r__SLSUBBSN.hru & Average slope length (m) & 0.02 & -0.05 & 0.4 \\
\hline
\end{tabular}

1 'r_ ' - indicates relative change; 'v__' - indicates replacement by a new value; suffixes '.gw', '.swq', etc. - SWAT file extensions. 
TABLE 2. Fitted parameter values and optimal parameter ranges calculated using SUFI-2 during calibration of TSS, $\mathrm{N}-\mathrm{NO}_{3}$ and $\mathrm{P}-\mathrm{PO}_{4}$ loads

\begin{tabular}{|c|c|c|c|c|}
\hline Parameter name $^{1}$ & Definition & $\begin{array}{l}\text { Fitted } \\
\text { value }\end{array}$ & $\begin{array}{l}\text { Mini- } \\
\text { mum } \\
\text { value }\end{array}$ & $\begin{array}{l}\text { Maxi- } \\
\text { mum } \\
\text { value }\end{array}$ \\
\hline 1 & 2 & 3 & 4 & 5 \\
\hline \multicolumn{5}{|c|}{ TSS } \\
\hline $\mathrm{r}$ __USLE_K.sol & USLE equation soil erodibility $(\mathrm{K})$ factor (-) & 0.52 & 0.3 & 0.7 \\
\hline v__CH_COV2.rte & The channel cover factor $(-)$ & 1.92 & 1.9 & 3 \\
\hline r_CH_N2.rte & Manning's $n$-value for the main channel (-) & 0.62 & 0.42 & 0.62 \\
\hline v_RES_D50.res & $\begin{array}{l}\text { Median particle diameter of sediment in } \\
\text { reservoir }(\mu \mathrm{m})\end{array}$ & 7.76 & 2 & 8 \\
\hline \multicolumn{5}{|c|}{$\mathrm{N}-\mathrm{NO}_{3}$} \\
\hline $\mathrm{v} \_$CDN.bsn & Denitrification exponential rate coefficient (-) & 0.004 & 0 & 0.3 \\
\hline $\mathrm{v} \_$RCN.bsn & Concentration of nitrogen in rainfall $(\mathrm{mg} / \mathrm{l})$ & 1.73 & 1.5 & 1.75 \\
\hline v_CMN.bsn & $\begin{array}{l}\text { Rate factor for humus mineralization of acti- } \\
\text { ve organic nutrients (-) }\end{array}$ & 0.0021 & 0.002 & 0.0024 \\
\hline $\mathrm{v} \_$SDNCO.bsn & Denitrification threshold water content (-) & 0.941 & 0.94 & 0.96 \\
\hline $\mathrm{v} \_$NPERCO.bsn & Nitrate percolation coefficient (-) & 0.71 & 0.7 & 0.87 \\
\hline $\mathrm{v} \_$RSDCO.bsn & Residue decomposition coefficient (-) & 0.058 & 0.05 & 0.07 \\
\hline r_SOL_NO3.chm & $\begin{array}{l}\text { Initial } \mathrm{NO}_{3} \text { concentration in the soil layer } \\
\text { (mg N/kg soil, dry weight) }\end{array}$ & -0.01 & -0.1 & 0.05 \\
\hline v_SOL_ORGN.chm & $\begin{array}{l}\text { Initial organic } \mathrm{N} \text { concentration in the soil } \\
\text { layer (mg N/kg soil, dry weight) }\end{array}$ & 578.9 & 570 & 640 \\
\hline $\mathrm{v} \_$_BC3.swq & $\begin{array}{l}\text { Rate constant for hydrolysis of organic } \mathrm{N} \text { to } \\
\mathrm{NH}_{4} \text { in the reach at } 20^{\circ} \mathrm{C}(1 / \text { day })\end{array}$ & 0.34 & 0.32 & 0.35 \\
\hline $\mathrm{v} \_\mathrm{AI} 1 . \mathrm{wwq}$ & Fraction of algal biomass that is nitrogen (-) & 0.0754 & 0.075 & 0.081 \\
\hline v_HLIFE_NGW.gw & $\begin{array}{l}\text { Half-life of nitrate in the shallow aquifer } \\
\text { (days) }\end{array}$ & 1.73 & 1 & 4 \\
\hline v_BIOMIX.mgt & Biological mixing efficiency $(-)$ & 0.34 & 0.3 & 0.44 \\
\hline \multicolumn{5}{|c|}{$\mathrm{P}-\mathrm{PO}_{4}$} \\
\hline v__ RSDIN.hru & Initial residue cover $(\mathrm{kg} / \mathrm{ha})$ & 5676 & 3894 & 6039 \\
\hline v__PPERCO.bsn & Phosphorus percolation coefficient $\left(\mathrm{m}^{3} / \mathrm{Mg}\right)$ & 12.52 & 11.78 & 13.49 \\
\hline $\mathrm{v}$ _PSP.bsn & Phosphorus availability index (-) & 0.189 & 0.13 & 0.26 \\
\hline $\mathrm{v} \_$RSDCO.bsn & Residue decomposition coefficient (-) & 0.074 & 0.047 & 0.088 \\
\hline $\mathrm{v} \_$_BC4.swq & $\begin{array}{l}\text { Rate constant for mineralization of organic } \mathrm{P} \\
\text { to dissolved } \mathrm{P} \text { in the reach at } 20^{\circ} \mathrm{C}(1 / \text { day })\end{array}$ & 0.345 & 0.26 & 0.41 \\
\hline r_SOL_SOLP().chm & $\begin{array}{l}\text { Initial soluble P concentration in soil layer } \\
\text { (mg P/kg soil, dry weight) }\end{array}$ & -0.137 & -0.15 & 0.05 \\
\hline v_SOL_ORGP().chm & $\begin{array}{l}\text { Initial humic organic phosphorus in soil layer } \\
\text { (mg P/kg soil, dry weight) }\end{array}$ & 343 & 275 & 358 \\
\hline v_ERORGP.hru & $\begin{array}{l}\text { Phosphorus enrichment ratio for loading with } \\
\text { sediment (-) }\end{array}$ & 1.70 & 1.29 & 2.22 \\
\hline
\end{tabular}


Table 2 cont.

\begin{tabular}{|l|l|c|c|c|}
\hline \multicolumn{1}{|c|}{1} & \multicolumn{1}{|c|}{2} & \multicolumn{1}{|c|}{3} & 4 & 5 \\
\hline v__GWSOLP.gw & $\begin{array}{l}\text { Concentration of soluble phosphorus in } \\
\text { groundwater contribution to streamflow from } \\
\text { subbasin }(\mathrm{mg} \text { P/l) }\end{array}$ & 0.070 & 0.03 & 0.116 \\
\hline v_AI2.wwq & Fraction of algal biomass that is phosphorus & 0.013 & 0.011 & 0.0132 \\
\hline v_CH_OPCO.rte & $\begin{array}{l}\text { Organic phosphorus concentration in the } \\
\text { channel (mg/l) }\end{array}$ & 38.8 & 23 & 41 \\
\hline v_MUMAX.wwq & $\begin{array}{l}\text { Maximum specific algal growth rate at } 20^{\circ} \mathrm{C} \\
(1 / \text { day) }\end{array}$ & 1.73 & 1.61 & 2.07 \\
\hline v_RHOQ.wwq & Algal respiration rate at $20^{\circ} \mathrm{C}(1 /$ day $)$ & 0.350 & 0.29 & 0.382 \\
\hline
\end{tabular}

1 'r__ ' - indicates relative change; ' $\mathrm{V}_{\text {_ }}$ '- indicates replacement by a new value; suffixes '.gw', 'swq', etc. - SWAT file extensions.

three years, i.e. the simulation start was set to 1 January 1995. This allowed stabilizing the initial soil moisture content as well as soil nitrogen and phosphorus pools.

\section{RESULTS AND DISCUSSION}

Figures 2 and 3 illustrate simulated versus observed flows, TSS load, $\mathrm{N}_{-} \mathrm{NO}_{3}$ load and $\mathrm{P}_{-} \mathrm{PO}_{4}$ load, for the calibration and validation periods, respectively. The graphs illustrating variability of discharge are presented with daily time step, whereas other graphs with bi-monthly time step. The assessment criteria of hydrological model performance are varied in literature. For the SWAT model the most commonly used criteria were developed by Moriasi et al. (2007). According to these criteria, simulation of daily discharge by SWAT can be assessed as good. Both NSE and $\mathrm{R}^{2}$ exceed 0.7 in calibration period and percent bias does not exceed $10 \%$ (Table 3). The underestimation of runoff occurs usually in the first quarter of the year (January - March) which is the high flow period, with frequent snowmelt and rain events.

Figures 2 and 3 present discharge simulation results only for the Reda at Wejherowo, whereas two other flow gauges situated upstream of Wejherowo (Fig. 1A) were used as well in calibration and validation. The goodness-of-fit measures were only a little worse for those stations than for Wejherowo; NSE and $\mathrm{R}^{2}$ were equal to 0.58 and 0.65 for Zamostne and 0.60 and 0.60 for Bolszewo.

The Reda catchment is characterised by the highest mean specific runoff ( $q$, mean discharge per unit area) in the Polish Plain, exceeding $10 \mathrm{l} / \mathrm{s} / \mathrm{km}^{2}$ (Stachý and Biernat 1987, Bogdanowicz et al. 2007). Furthermore, $q$ exhibits a clear gradient from the seaside $\left(5-61 / \mathrm{s} / \mathrm{km}^{2}\right)$ towards the upland $\left(12-15 \mathrm{l} / \mathrm{s} / \mathrm{km}^{2}\right)$. A similar scale of spatial variability was obtained as a result of modelling in SWAT.

Another feature of the Reda catchment is very high (compared to other catchments in the Polish Plain) contribution of groundwater in total runoff. According to the map of groundwater contribution to streamflow, two classes are 
A.

Discharge

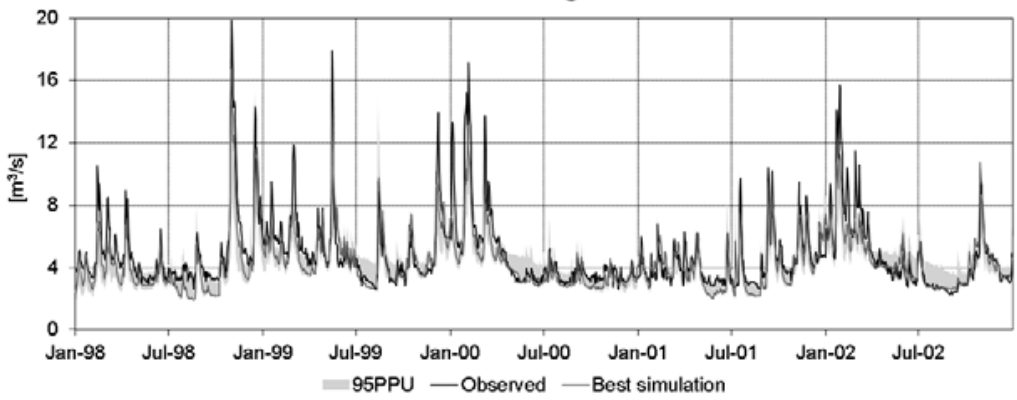

B.

TSS load

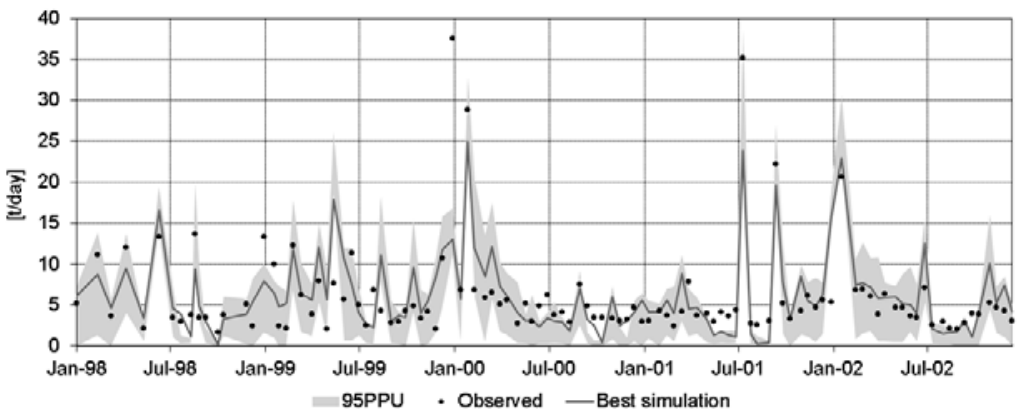

c.

$\mathrm{N}-\mathrm{NO}_{3}$ load

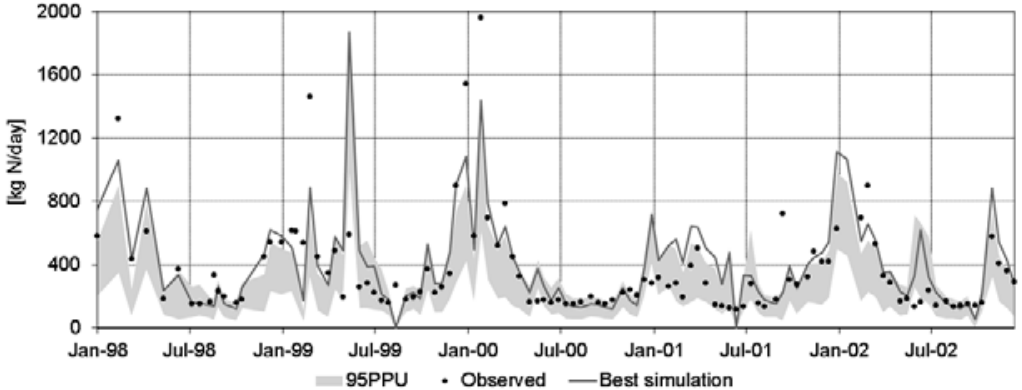

D.

$\mathrm{P}_{-} \mathrm{PO}_{4}$ load

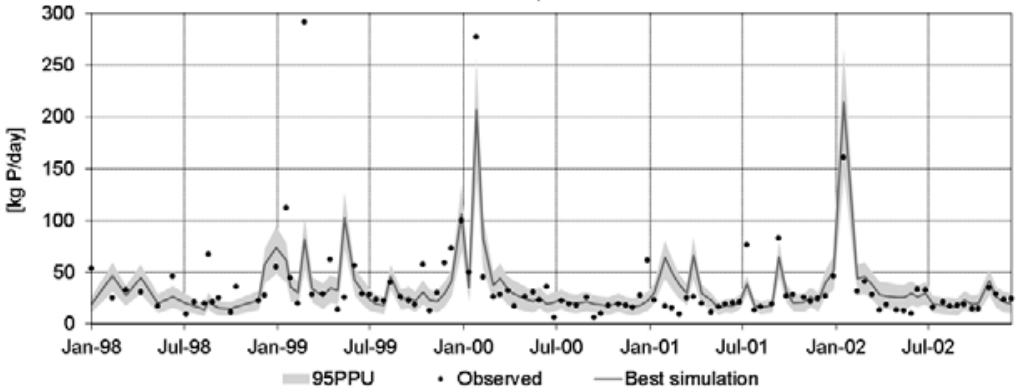

FIGURE 2. Calibration plots for discharge (A), TSS load (B), N-NO $\mathrm{N}_{3}$ load (C) and P-PO 4 load (D) - time period 1998-2002 
A.

Discharge

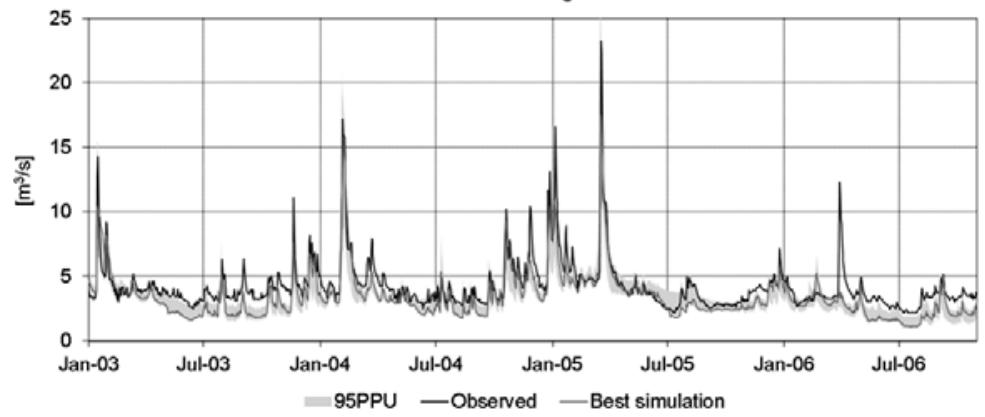

B.

TSS load

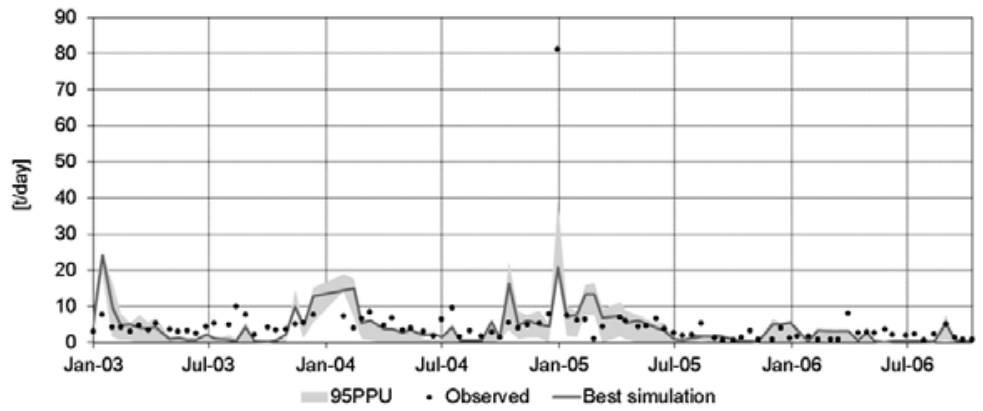

C.

$\mathrm{N}-\mathrm{NO}_{3}$ load

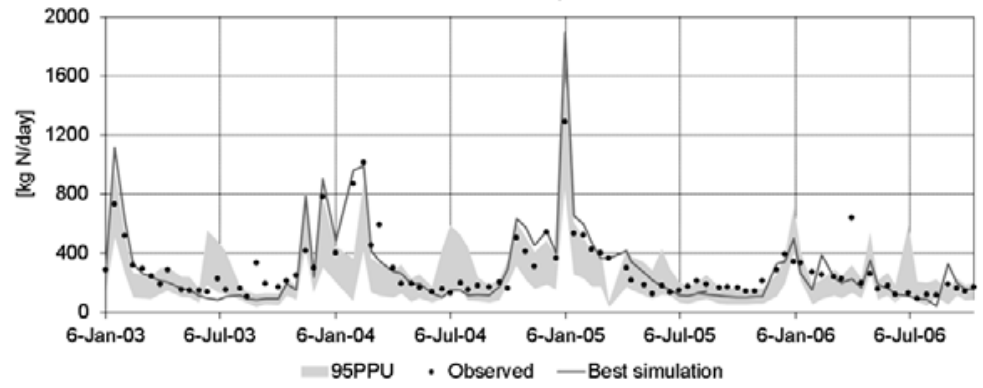

D.

$\mathrm{P}^{-\mathrm{PO}_{4}}$ load

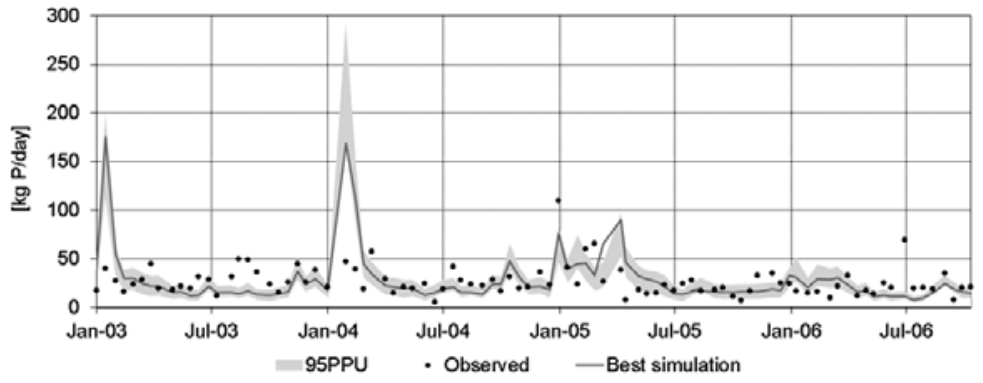

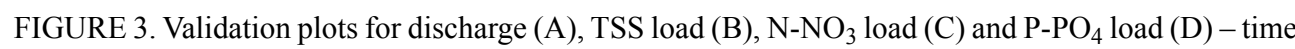
period 2003-2006 
TABLE 3. Calibration and validation goodness-of-fit measures at Wejherowo gauging station (NSE - Nash-Sutcliffe Efficiency; $\mathrm{R}^{2}$ - coefficient of determination; PBIAS - percent bias)

\begin{tabular}{|l|c|c|c|c|c|c|}
\hline Specification & \multicolumn{3}{|c|}{ Calibration period } & \multicolumn{3}{c|}{ Validation period } \\
\hline Variable & NSE & $\mathrm{R}^{2}$ & PBIAS [\%] & NSE & $\mathrm{R}^{2}$ & PBIAS [\%] \\
\hline Discharge & 0.75 & 0.79 & -8 & 0.61 & 0.78 & -18 \\
\hline Sediment load & 0.55 & 0.58 & 10 & 0.22 & 0.23 & -12 \\
\hline N-NO3 load & 0.62 & 0.62 & -4 & 0.64 & 0.83 & 3 \\
\hline P-PO4 load & 0.53 & 0.53 & -6 & -1.78 & 0.12 & 7 \\
\hline
\end{tabular}

present in the Reda watershed: $60-75 \%$ and above $75 \%$ (Orsztynowicz 1988). A SWAT-based estimate equals $69 \%$, which shows a good match with the map of Orsztynowicz (1988). The model performed reasonably well in simulation of low flow magnitude. Low flows are exceptionally high in the Reda watershed (simulated and observed mean annual minimum specific runoff equal to 5.4 and $6.2 \mathrm{l} / \mathrm{s} / \mathrm{km}^{2}$, respectively) and discharge variability is also exceptionally low. Modelled and observed coefficient of variation of daily flows equalled to 0.47 and 0.48 , respectively.

Simulation of $\mathrm{N}^{-\mathrm{NO}_{3}}$ load is good, which is reflected by relatively high values of performance measures (NSE for calibration and validation period reached 0.62 and 0.64 , respectively) and visual inspection of plots in Figures 2C and 3C. It is noteworthy that SWAT correctly simulates seasonal variability of $\mathrm{N}-\mathrm{NO}_{3}$ load - the highest values are observed during winter and the lowest during summer. Similar pattern was found for British agricultural catchments by Heathwaite and Johnes (1996), who suggested that

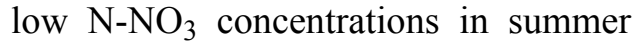
months coincide with low discharge and low dissolved oxygen concentrations. In the Reda catchment observed $\mathrm{N}_{-} \mathrm{NO}_{3}$ concentrations are strongly correlated with discharge ( $\mathrm{R}^{2}$ equal to 0.45 for the time period 1998-2006). The mass balance of transported nitrate load is well conserved - PBIAS for calibration and validation periods is equal to $-4 \%$ and $3 \%$, respectively.

Simulation results for sediment load are worse than those for discharge and $\mathrm{N}-\mathrm{NO}_{3}$ loads, especially during validation period (Fig. 3B). It is noteworthy that the temporal variability of sediment load transported through the River Reda at Wejherowo gauging station is relatively low, which is determined by low variability of discharge and generally low TSS concentration (the values exceeding $50 \mathrm{mg} / \mathrm{l}$ occurred only twice per 206 observations carried out in years 1998-2006).

The results of $\mathrm{P}_{-} \mathrm{PO}_{4}$ calibration are good for calibration period and poor for validation period. NSE for calibration period equals 0.53 , whereas for validation period -1.78 . This poor result is partly influenced by unsatisfactory TSS load simulation during validation period, as significant amount of $\mathrm{P}_{-} \mathrm{PO}_{4}$ is transported with sediment. Another possible reason for such a large difference between calibration and validation might be the lack of homogeneity of observed data between two periods. Both the loads and concentrations of $\mathrm{P}-\mathrm{PO}_{4}$ demonstrate 
smaller seasonal variability compared to corresponding loads and concentrations

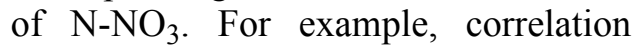
between $\mathrm{P}_{-} \mathrm{PO}_{4}$ concentration and discharge was observed only for the calibration period $\left(\mathrm{R}^{2}=0.15\right.$, compared to 0 for validation period). Figure 4 illustrates

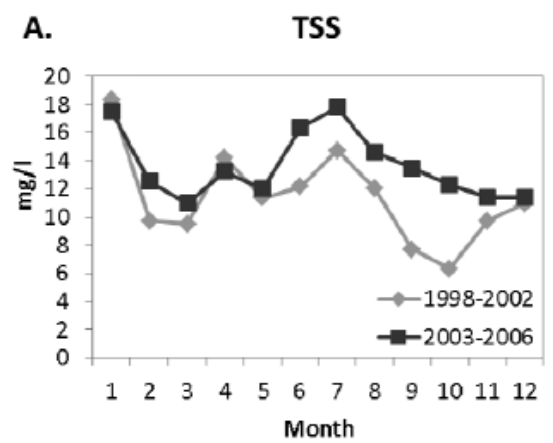

B.

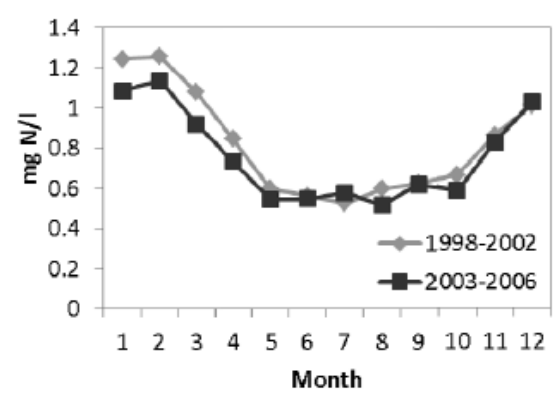

c.

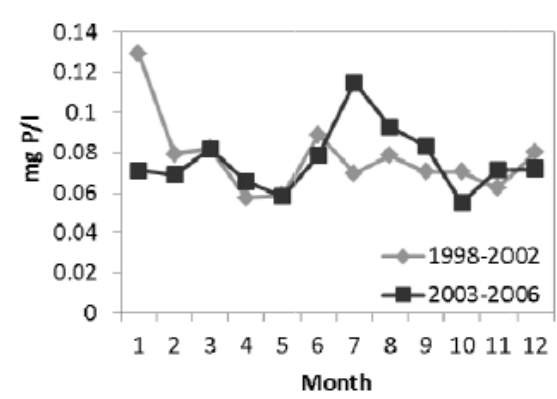

FIGURE 4. Observed mean monthly concentrations of TSS (A), N-NO 3 (B) and $\mathrm{P}_{-} \mathrm{PO}_{4}$ for calibration (1998-2002) and validation (2003-2006) periods monthly variability of the observed mean TSS, N-NO 3 and $\mathrm{P}_{-} \mathrm{PO}_{4}$ concentrations in calibration and validation periods. In the calibration period maximum values of $\mathrm{P}_{-} \mathrm{PO}_{4}$ concentration occurred in winter, whereas in the validation period in summer. Also for TSS monthly variability differed to a large extent between two periods. In contrast, $\mathrm{N}-\mathrm{NO}_{3}$ concentrations were quite similar in both periods. Hence, it is argued that this lack of homogeneity explains observed differences in goodness-of-fit measures in validation period, that were good for $\mathrm{N}-\mathrm{NO}_{3}$ and poor for sediment and $\mathrm{P}_{-} \mathrm{PO}_{4}$. The model was not able to simulate accurately maximum $\mathrm{P}_{-} \mathrm{PO}_{4}$ loads observed in summer months, whereas in winter of 2003 and 2004 maximum loads were simulated by the model despite not being present in measurements. It is noteworthy, however, that the mass balance of $\mathrm{P}_{-} \mathrm{PO}_{4}$ was simulated accurately (percent bias for calibration and validation periods yielded $-2 \%$ and $5 \%$, respectively).

The plots shown in Figures 2 and 3 illustrate the best fit simulation results against the observations as well as the 95PPU uncertainty band corresponding to the final parameter ranges obtained in SUFI-2. In addition the uncertainty measures were presented separately in Figure 5, which shows that $p$-factor reached similar values for all variables (75-77\%) in calibration period. The variability of $r$-factor was significantly higher: high for sediment (1.06) compared to the rest of variables $(0.61-0.72)$. During validation period the uncertainty measures were slightly worse than in calibration period for discharge and significantly worse for $\mathrm{P}-\mathrm{PO}_{4}$. 


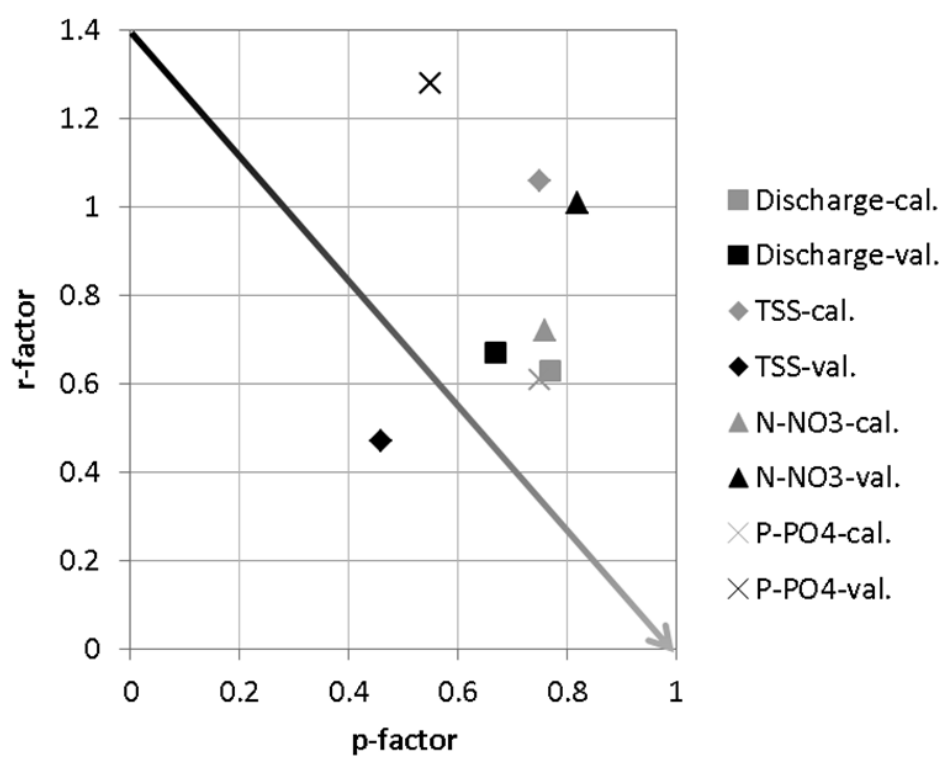

FIGURE 5. Plot of two uncertainty measures ( $p$-factor against $r$-factor) for different model outputs in calibration and validation periods. The arrow direction (black-grey gradient) indicates decreasing uncertainty reflected by increasing $p$-factor and decreasing $r$-factor

Parameter values related to the best simulation found using SUFI-2 (cf. Tables 1-2) were written into the model. Afterwards a 20-year-long simulation run was executed which defined the current hydrological and geochemical conditions in the Reda catchment. Mean annual total runoff was equal to $299 \mathrm{~mm}$. Because there was a very low proportion of surface runoff in water yield (8\%) authors found that an area-specific load of $\mathrm{N}-\mathrm{NO}_{3}$ in surface runoff was only $0.44 \mathrm{~kg} \mathrm{~N} / \mathrm{ha} /$ year, compared to 2.29 and $1.15 \mathrm{~kg} \mathrm{~N} / \mathrm{ha} /$ year in subsurface runoff and baseflow, respectively. This difference can be explained by high percolation of dominating sandy soils contributing to high $\mathrm{N}-\mathrm{NO}_{3}$ leaching into the shallow aquifer, and by relatively high slopes in the study area contributing to high $\mathrm{N}-\mathrm{NO}_{3}$ loading in subsurface runoff. Mean annual TSS loads were in accor- dance with other data sources (Szymczak and Piekarek-Jankowska 2007) as were mean nutrient loads ${ }^{1}$ at the watershed outlet.

The simulation results for the Reda catchment can be compared with other modelling studies in small agricultural catchments in northern Europe. Lam et al. (2009) obtained similar accuracy of simulations for both the magnitude and the dynamics of nitrate load, maintaining the seasonal variability. They also found a strong correlation between $\mathrm{N}-\mathrm{NO}_{3}$ concentration and discharge explaining the underestimation of loads in winter season occurring in Kielstau catchment due to lower peak flows simulated by the model. Similar results were presented by Schmalz et al. (2008) for the same catch-

\footnotetext{
${ }^{1}$ http://baltyk.imgw.gdynia.pl/warunki/odplyw zanieczyszczen.html (last accessed 28.03.2013).
} 
ment where underestimation of loads in winter season was explained by higher nitrogen mobilisation not represented by the model. In the Reda catchment such underestimation has not been noted, though. In contrast, Glavan et al. (2011) reported poor goodness-of-fit for nitrate simulation using SWAT in the Axe catchment in south-western England. Their results were particularly poor for daily concentrations (the model showed excessive variability compared to observations), while they were substantially better for nitrate loads. Interestingly, Glavan et al. (2011) showed excellent model performance for phosphate simulation. This can be partly explained by the fact that point sources constitute almost half of the $\mathrm{P}_{-} \mathrm{PO}_{4}$ loads in this catchment, while in the Reda catchment it is approximately $5 \%$. Furthermore, phosphate concentrations and loads in the Axe have quite regular seasonal variability, with peaks observed in summer and lowest values in winter. In the Reda catchment no such seasonality pattern in $\mathrm{P}_{-} \mathrm{PO}_{4}$ was observed. Finally, Ekstrand et al. (2010) who applied SWAT for modelling (total) phosphorus losses in five catchments in central Sweden obtained results varying from unsatisfactory to good. They pointed out two potential reasons for unsatisfactory model predictions that in our opinion fit as well to the Reda case. The first reason is that the prerequisite for obtaining satisfactory results for validation period is that the range of hydroclimatological conditions is similar as in calibration period, which was not the case for the Reda catchment as manifested by the mean monthly phosphates concentrations (cf. Fig. 4C). The second reason is lack of using flow-proportional measure- ments of nutrient concentrations, which was the case both in Sweden and Poland. As shown in Figure 3D the model simulated two large peaks in $\mathrm{P}_{-} \mathrm{PO}_{4}$ loads in winter 2003 and 2004 that were not visible at all in measured data. However, it is possible that elevated concentrations were present in reality, but were not captured by rare nutrient concentration sampling.

\section{CONCLUSIONS}

The first step of this study was development of the SWAT model set-up using available input data characterising various spatial attributes of the Reda catchment. The accomplishment of the first part allowed to use the model to investigate the variables of interest. Further steps conducted during the research led to following conclusions:

- The accurate description and parameterization of basin-scale models is extremely important in the process of calibration and validation in which the model simulations have to meet the observations. The results of this study confirm that the complexity of the model set-up was good enough for providing meaningful model estimates. This is not evident, since the interplay between the catchment size and model setup complexity plays a crucial role for the quality of model simulations (Piniewski 2012).

- SWAT is an appropriate model for simulating water yield and nutrient loading in catchment scale in Polish conditions. Among the investigated variables, the most reliable simulations were obtained for discharge and nitrates, and slightly worse for TSS and phosphates. 
- Sediment yield modelling is challenging in Polish conditions due to generally low erosion rates and low TSS concentrations. Simulation of nitrate loads is more straightforward, since this nitrogen species is very mobile and well correlated with discharge. Simulation of phosphate loads appeared to be challenging as well, due to several reasons: partly because of problems with sediment modelling, and partly because of the uncertainty in management practices and soil phosphorus content. Lack of homogeneity between calibration and validation periods and of flow-proportional nutrient concentration sampling is another potential reason explaining partly unsatisfactory $\mathrm{P}_{-} \mathrm{PO}_{4}$ simulation results.

- Provided parameter ranges can be helpful in setting up and calibrating SWAT in similar meso-scale catchments in Poland. The validated model of the Reda catchment can be applied for studies investigating the impact of climate and land use change on water quantity and quality, as well as the Best Management Practices (BMP) efficiency. Provided estimates of water, sediment and nutrient loading from the Reda catchment are useful for environmental assessment and hydrodynamic modelling of the Puck Lagoon.

- This study has set the scene for model scenario analyses including climate and land use change effects on nutrient loading to the Baltic Sea (Piniewski et al. 2013)

\section{Acknowledgements}

This study was partly funded by the Baltic Compass project (part-financed by the European Union, within the European Regional Development Fund and European Neighbourhood and Partnership Instrument). Authors would like to acknowledge the partners of the Baltic Compass project, Halina Burakowska and Włodzimierz Krzymiński from the Institute of Meteorology and Water Management in Gdynia for their continuous help and thank an anonymous reviewer for comments and suggestions.

\section{REFERENCES}

ABBASPOUR K. 2008: SWAT-CUP2: SWAT Calibration and Uncertainty Programs - a user manual. Department of Systems Analysis, Integrated Assessment and Modelling (SIAM), Eawag, Swiss Federal Institute of Aquatic Science and Technology, Duebendorf.

AMATYA D.M., HALEY E.B., LEVINE N.S., CALLAHAN T.J., RADECKI-PAWLIK A., JHA M.K. 2008: Calibration and validation of the SWAT model for a forested watershed in coastal South Carolina. ASABE Annual International Meeting. Rhode Island Convention Center Providence, Rhode Island June 29 - July 2.

ARNOLD J.G., MORIASID.N., GASSMAN P.W., ABBASPOUR K.C., WHITE M.J., SRINIVASAN R., SANTHI C., HARMEL R.D., Van GRIENSVEN A., Van LIEW M.W., KANNAN N., JHA M.K. 2012: SWAT: model use, calibration, validation. American Society of Agricultural and Biological Engineers 55(4): 1491-1508.

BOGDANOWICZ R., CIEŚLIŃSKI R., DRWAL J., CYSEWSKI A. 2007: Estimation of the local riverine pollution load to the lagoon on the southern Baltic coast (the Puck Lagoon). Sowriemiennyj naucznyj wiestnik 5: 28-36. 
BROWN L.C., BARNWELL T.O. 1987: The Enhanced Stream Water Quality Models QUAL2E and QUAL2E-UNCAS: Documentation and User Manual. Cooperative Agreement No. 811883, Environmental Research Laboratory, Office of Research and Development, U.S. Environmental Protection Agency, Georgia.

EKSTRAND S., WALLENBERG P., DJODJIC F. 2010: Process based modelling of phosphorus losses from arable land. Ambio 39: 100-115.

GLASBY G.P., SZEFER P. 1998: Marine pollution in Gdansk Bay, Puck Bay and the Vistula Lagoon, Poland: An overview. Science of the Total Environment 212: 49-57.

GLAVAN M., WHITE S., HOLMAN I.P. 2011: Evaluation of River Water Quality Simulations at a Daily Time Step - Experience with SWAT in the Axe Catchment, UK. Journal of Environmental Management 103: 142-153.

HEATHWAITE A.L., JOHNES P.J. 1996: Contribution of nitrogen species and phosphorus fractions to stream water quality in agricultural catchments. Hydrological Processes 10: 971-983.

HOANG L., Van GRIENSVEN A., Van Der KEUR P., REFSGAARD J.C., TROLDBORG L., NILSSON B., MYNETT A. 2012: Comparison and evaluation of model structures for the simulation of pollution fluxes in a tile-drained river basin. Journal of Environmental Quality. DOI: $10.2135 /$ jeq2011.0398.

KUNDZEWICZ Z.W., ZALEWSKI M., KĘDZIORAA., PIERZGALSKI E. 2010: Zagrożenia związane $\mathrm{z}$ wodą [Hazards associated with water]. Nauka 4: 87-96 (in Polish).

LAM Q.D., SCHMALZ B., FOHRER N. 2009: Ecohydrological modelling of water discharge and nitrate loads in a mesoscale lowland catchment, Germany. Adv. Geosci. 21: 49-55.

MIODIUSZEWSKI W. 2008: Czy Polska jest krajem ubogim w wodę [Is Poland a country with water shortages]. Gospodarka Wodna 5: 186-193 (in Polish).
MORIASI D.N., ARNOLD J.G., Van LIEW M.W., BINGER R.L., HARMEL R.D., VEITH T.L. 2007: Model evaluation guidelines for systematic quantification of accuracy in watershed simulations. Transactions of the Asabe 50(3): 885-900.

NEITSCH S., ARNOLD J., KINIRY J., WILLIAMS J. 2011: Soil and Water Assessment Tool theoretical documentation version 2009. Tech. Rep. TR-406, Texas A\&M University. Retrieved 28 March, 2013, from http://twri.tamu.edu/ reports/2011/tr406.pdf.

ORSZTYNOWICZ J. 1988: Studium naukowo-badawcze do Atlasu hydrogeologicznego Polski. Średnie roczne i wieloletnie odpływy podziemne na obszarze Polski w okresie 1951-1980 [Research and scientific study in hydrogeological atlas of Poland. Mean annual and long-term groundwater outflow in Poland 1951-1980]. IMiGW, Zakład Dynamiki Wód Podziemnych, Warszawa (in Polish).

OSTOJSKI M.S. 2012: Modelowanie procesów odprowadzania do Bałtyku związków biogennych na przykładzie azotu i fosforu ogólnego [Modelling of biogenic substances transport into the Baltic Sea based on an example of total nitrogen and total phosphorus]. Wydawnictwo Naukowe PWN, Warszawa (in Polish).

PINIEWSKI M. 2012: Scenario-based impact assessment of global and regional change on the semi-natural flow regime. GRIN Publishing, Munich.

PINIEWSKI M., KARDEL I., GIEŁCZEWSKI M., MARCINKOWSKI P., OKRUSZKO T. 2013: Climate Change and Agricultural Development: Adapting Polish Agriculture to Reduce Future Nutrient Loads in a Coastal Watershed. AMBIO accepted. DOI 10.1007/ s13280-013-0461-z.

SCHMALZ B., BIEGER K., FOHRER N. 2008: A method to assess instream water quality - the role of nitrogen entries in a North German rural lowland catchment. Adv. Geosci. 18: 37-41. 
SRINIVASAN R., RAMANARAYANAN T.S., ARNOLD J.G., BEDNARZ S.T. 1998: Large area hydrologic modeling and assessment part II: model application. JAWRA Journal of the American Water Resources Association 34 (1): 91-101.

SMARZYŃSKAK. 2013: Odpływ związków azotu $\mathrm{z}$ terenów intensywnego rolnictwa w świetle badań terenowych i analiz modelowych [Runoff of nitrogen compounds from agriculturally intensive areas in the light of field surveys and model analyses]. $\mathrm{PhD}$ thesis (typescript). Institute of Technology and Life Sciences, Bydgoszcz (in Polish).

STACHÝ J., BIERNAT B. 1987: Odpływ rzeczny. Średni odpływ jednostkowy [In:] J. Stachý (ed.). Atlas Hydrologiczny Polski, IMGW. Wyd. Geol., Warszawa: 56 (in Polish).

SZYMCZAK E., PIEKAREK-JANKOWSKA H. 2007: The transport and distribution of the river load from the Reda river into the Puck Lagoon (Southern Baltic Sea, Poland). Oceanological and Hydrobiological Studies, International Journal of Oceanography and Hydrobiology 36 (1): 103-124.

TATTARI S., KOSKIAHO J., BÄRLUND I., JAAKKOLA E. 2009: Testing a river basin model with sensitivity analysis and autocalibration for an agricultural catchment in SW Finland. Agricultural and Food Science 18: 428-439.

WILLIAMS J.R. 1990: The Erosion-Productivity Impact Calculator (EPIC) Model: A Case History. Philosophical Transactions: Biological Sciences 329(1255): 421-428.

WILLIAMS J.R., BERNDT H.D. 1977: Sediment yield prediction based on watershed hydrology. Trans. Am. Soc. Agric. Eng. 20: 1100-1104.

Streszczenie: Modelowanie odplywu oraz ładunków azotanów i fosforanów odprowadzanych ze zlewni Redy do Zalewu Puckiego przy uzyciu modelu SWAT. W niniejszej pracy zaprezentowano przykład zastosowania modelu SWAT (Soil and Water Assessment Tool) w rolniczej, przybrzeżnej zlewni Redy o powierzchni $482 \mathrm{~km}^{2}$ usytuowanej w północnej części Polski. Głównym celem pracy było przeprowadzenie kalibracji i weryfikacji modelu na podstawie przepływów dobowych i parametrów jakościowych wód (ładunki zawiesin [TSS], azotanów $\left[\mathrm{N}-\mathrm{NO}_{3}\right]$ i fosforanów $\left[\mathrm{P}-\mathrm{PO}_{4}\right]$ z częstotliwością pomiarów co dwa tygodnie). Kalibracja i weryfikacja zostały przeprowadzone przy użyciu programu SWAT-CUP i algorytmu SUFI-2 (Sequential Uncertainty Fitting Version 2). Współczynnik Nasha-Sutcliffe'a, zdefiniowany jako funkcja celu, wyniósł dla przepływu 0,75 i 0,61 odpowiednio dla okresu kalibracji i weryfikacji. Dla ładunków TSS, N-NO $\mathrm{N}_{3} \mathrm{P}_{-} \mathrm{PO}_{4}$ współczynnik ten wyniósł odpowiednio $0,56,0,62,0,53$ dla okresu kalibracji oraz $0,22,0,64,-1,78$ dla okresu weryfikacji. Uzyskane wyniki można ocenić jako satysfakcjonujące lub dobre w przypadku okresu kalibracji, natomiast w okresie weryfikacji jakość symulacji ładunków TSS i P-PO 4 uznano za nieco gorszą, co może być związane z brakiem jednorodności pomiędzy tymi okresami. Wyniki te wskazują, że SWAT jest odpowiednim narzędziem do ilościowej oceny wielkości ładunków biogenów w rolniczych zlewniach Polski, szczególnie w przypadku azotanów. $\mathrm{Z}$ tego względu model może znaleźć zastosowanie w zarządzaniu zasobami wodnymi, w kwantyfikacji scenariuszy zmian klimatu i użytkowania ziemi oraz przy ocenie efektywności środków zaradczych stosowanych w rolnictwie.

Stowa kluczowe: zlewnia Redy, Zalew Pucki, model SWAT, biogeny, przepływ, kalibracja

MS. received December 2013

\section{Authors' address:}

Katedra Inżynierii Wodnej SGGW

ul. Nowoursynowska 166

02-787 Warszawa

Poland

e-mail: p.marcinkowski@levis.sggw.pl m.piniewski@levis.sggw.pl i.kardel@levis.sggw.pl m.gielczewski@levis.sggw.pl t.okruszko@levis.sggw.pl 